\title{
Development and Evaluation of BOD-DO Model for River Ghataprabha near Mudhol (India), using QUAL2K
}

\author{
P. B. Kalburgi ${ }^{\text {a }}$ R. N. Shareefa ${ }^{a}$, U. B. Deshannavar ${ }^{\text {b,* }}$ \\ ${ }^{a}$ Civil Engineering Department, Basaveshwar Engineering College, Bagalkot,587101, INDIA \\ ${ }^{b}$ Department of Chemical Engineering, KLE DR. M. S. Sheshgiri College of Engineering \& Technology, \\ Belgaum, 590008, Karnataka, INDIA
}

\begin{abstract}
The present study involves the application of a water quality model QUAL2K for developing the BOD-DO model and evaluation of the results for a $50 \mathrm{~km}$ stretch of river Ghataprabha near Mudhol town of Bagalkot district, Karnataka. QUAL2K is a modeling framework for simulating river and stream water quality. Arc-GIS technique is used to obtain some hydro-geometric data of the river for input to model QUAL2K. For calibration and validation of the model, the BOD and DO values were monitored at six different locations. The calibrated model was validated to predict water quality using a different set of data under different conditions. The performance of the model was evaluated using statistics based on Standard errors (SE), Normalized Mean Errors (NME) and Mean Multiplicative errors (MME). The SE and MME values for BOD and DO during calibration are, 1.41 (1.12) and1.28 (0.90), respectively. The values in the bracket show MME. Corresponding values for the validation are $1.27(1.09)$ and $1.10(0.96)$. These results show that the values predicted by the model are in close agreement with measured values.
\end{abstract}

Index Terms: Water quality modeling, QUAL2K, River pollution, River Ghataprabha, Calibration.

(C) 2015 Published by MECS Publisher. Selection and/or peer review under responsibility of the Research Association of Modern Education and Computer Science.

\section{Introduction}

In India, disposal of domestic sewage from cities and towns is the biggest source of pollution of surface water bodies which cause depletion of oxygen in water bodies. According to WHO estimate, about $80 \%$ of pollution in developing countries like India is caused by domestic wastes (Bhuvaneswaran \& Rajeswari, 1999). The unchecked urban growth across the country combined with poor government oversight means the problem is only getting worse gradually and the maintenance of the quality of river water will be a severe problem in the years to come.

* Corresponding author. Tel.: 00919740935126

E-mail address: deshannavar@gmail.com 
Mathematical models can be used to predict the changes in ambient water quality due to changes in discharges of waste water. They are typically used to establish priorities for reduction of existing waste water discharges or to predict the impacts of a proposed new discharge. With the use of mathematical models and modern computer tools it has become an easy technique to study the dynamics of the river system. The scientific activity of modeling has the capability to deliver customized solutions through identifying a variety of arrangements. This in turn offers inexhaustible opportunities of integration, analysis and evaluation of complex water quality problems, which will ultimately guide the planners, policy makers and decision makers to take quick steps to mitigate pollution problems and manage the water systems in a more scientific and comprehensive manner.

River Ghataprabha, during its flow through Bagalkot district in Karnataka state, receives untreated domestic waste from Mudhol town and other villages located on the bank of this river causing a serious threat to its water quality. This river is a primary source of drinking water to the people of many towns and villages located on the bank of this river. Considering the implications of water pollution on human and aquatic health, the effective management of this polluted segment of the river is of prime importance.

QUAL2K (Version 2.04) is a modeling framework for simulating river and stream water quality developed by Chapra, et al., (2005). It is intended to represent a modernized version of the QUAL2E (or Q2E) model (Brown \& Barnwell, 1987). Model is implemented within the Microsoft Windows environment. Numerical computations are programmed in Fortran 90. Excel is used as the graphical user interface. All interface operations are programmed in the Microsoft Office macro language: Visual Basic for Applications (VBA). The present study involves the calibration, validation and performance evaluation of a water quality model QUAL2K.

In this paper, a brief summary of the study area, description and implementation of QUAL2K model is provided in Section 2. Section 3 analyses the input data of the model. Validation and performance evaluation of the model are discussed in Section 4. Some conclusions are drawn in Section 5.

\section{Materials And Methods}

\subsection{Study area and database}

Mudhol town, a Taluka headquarter of Bagalkot district of Karnataka state is located in the western part of Bagalkot district at a distance of $74 \mathrm{~km}$. It lies between $16^{\circ}-06^{`}$ to $16^{\circ}-26^{`}$ north latitude and $75^{\circ}-02^{`}$ to $75^{\circ}$ $28^{\circ}$ east longitude. It is on the left bank of the Ghataprabha River and receives untreated domestic waste from Mudhol town and other villages located on the bank of this river. Population of Mudhol town is about 1.0 lakh (censes of 2011). Other villages situated on the bank of this stretch of the river are Dhavaleshwar, Chinchalkhandi and Budani having a population of 10000, 4000 and 7500, respectively. There is no sewage treatment facility for the Mudhol town and all the other villages. Domestic wastes from all these places are discharged directly into Ghataprabha River without any prior treatment. The river water is used for bathing, swimming, washing of the clothes, cattle and vehicles at all the above said places. All these human activities contribute significantly towards the pollution of the river. The major non point sources of pollution are excess run off from agricultural and urban areas. The point sources are the domestic waste from Mudhol town and other villages located on the bank of the river. The map of the stretch of river Ghataprabha selected for the present study is shown in Fig. 1. 


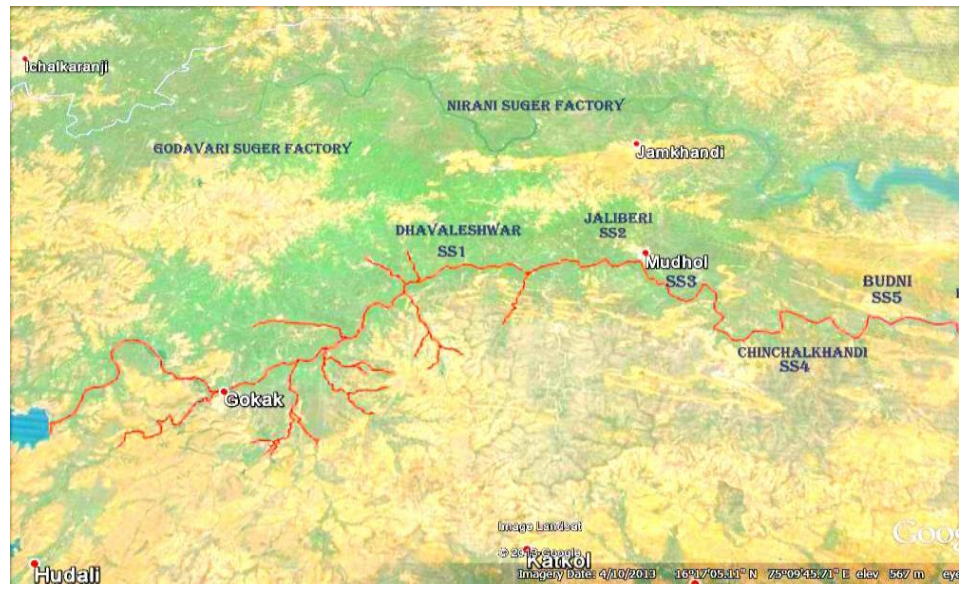

Fig. 1. Description of study area with sampling locations

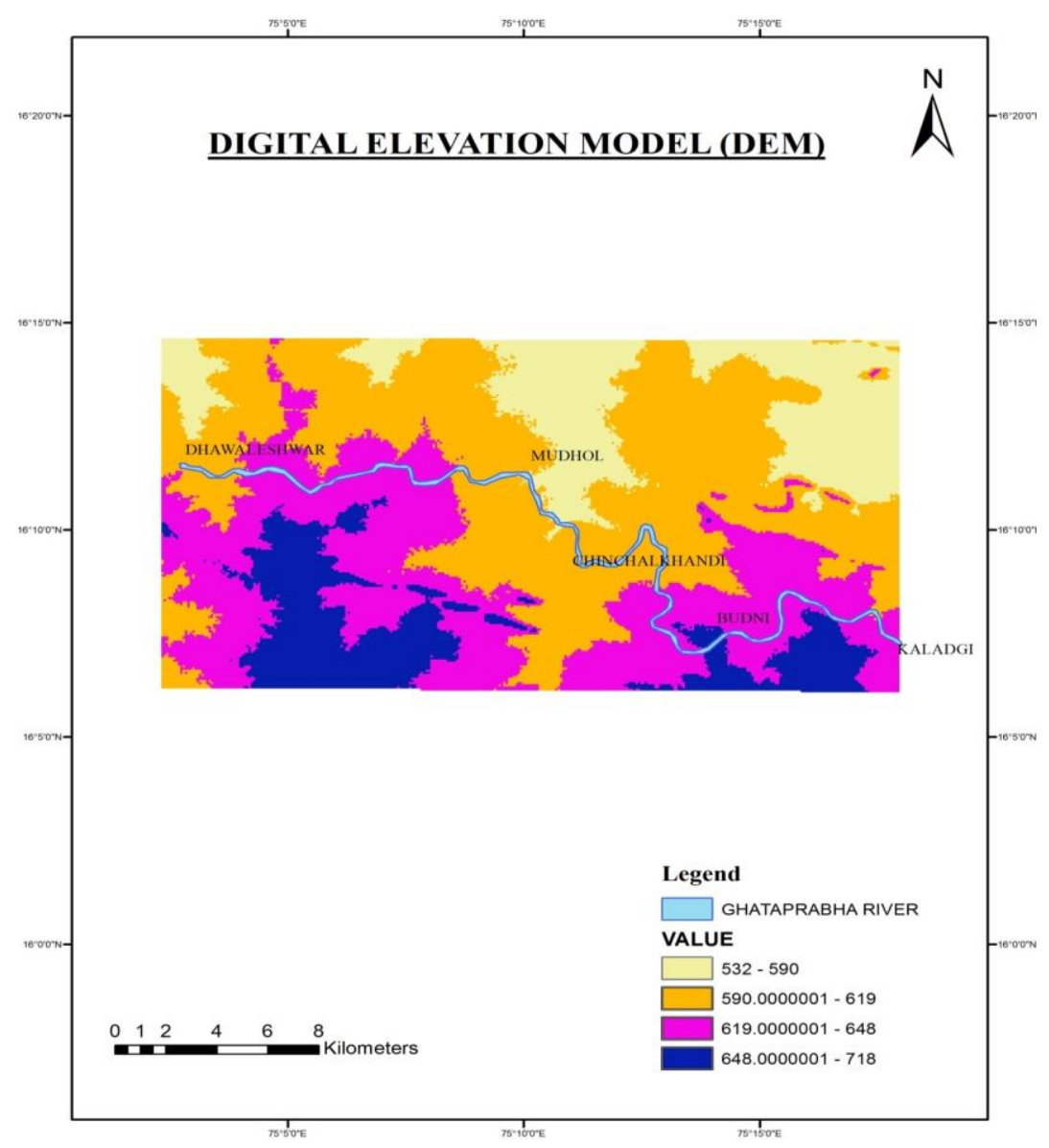

Fig. 2. Digital elevation model (DEM) for Ghatrabha River Using Arc-GIS 


\subsection{Remote sensing and GIS technique}

The hydraulic parameters like longitudinal slope and elevation of the study location from sea level etc., which are required for input to model QUAL2K, the Digital Elevation Model (DEM) and satellite image was used. This model was created using Arc-GIS and is shown in Fig. 2.

\subsection{Sampling and analysis}

Water samples at various distances from the selected stretch of the river were collected at about $15 \mathrm{~cm}$ depth (to avoid floating material) from three points across a location of the river $(1 / 3,1 / 2$ and $2 / 3)$ using the dip and grab sampling method and stored in pre-cleaned polythene bottles. To measure the head water flow of the main river, current meter was used to measure the velocity of the water at $0.6 d$ (where $d=$ depth of the water at any flow location) across the width of the river and the leveling staff was used to measure the water depth. The discharges from the point sources were calculated using the velocity and cross sectional area. All the analysis was done using standard methods given in (APHA, 1998).

\subsection{Description of the model}

QUAL2K is a river and stream water quality model and is modernized version of the QUAL2E. In the QUAL2K model the River is divided into several reaches which represent stretches of river that have constant hydraulic characteristics (e.g., slope, bottom width, etc.). Each reach is divided into segments which constitute the model's shortest parts of simulation. A steady-state flow balance is implemented for each model reach. The depth and velocity are calculated in one of three ways: weirs, rating curves, and Manning equations. The reaeration coefficient (at $20^{\circ} \mathrm{C}$ ) can be prescribed on the Reach Worksheet. Multiple loadings and withdrawals can be input to any element. It allows specifying many of the kinetic parameters on a reach-specific basis. For all but the bottom algae variables, a general mass balance for a constituent in an element is written as

$$
\frac{d c_{i}}{d t}=\frac{Q_{i-1}}{V_{i}} c_{i-1}-\frac{Q_{i}}{V_{i}} c_{i}-\frac{Q_{o u t, i}}{V_{i}} c_{i}+\frac{E_{i-1}^{\prime}}{V_{i}}\left(c_{i-1}-c_{i}\right)+\frac{E_{i}^{\prime}}{V_{i}}\left(c_{i+1}-c_{i}\right)+\frac{W_{i}}{V_{i}}+S_{i}
$$

where $W_{i}=$ the external loading of the constituent to element $i[\mathrm{~g} / \mathrm{d}$ or $\mathrm{mg} / \mathrm{d}]$, and $S_{i}=$ sources and sinks of the constituent due to reactions and mass transfer mechanisms $\left[\mathrm{g} / \mathrm{m}^{3} / \mathrm{d}\right.$ or $\left.\mathrm{mg} / \mathrm{m}^{3} / \mathrm{d}\right]$.

\subsection{Implementation of the model}

The data measured in the month of January 2014 were used for calibration. The calibration time step was set at 5.625 minute to avoid instability in the model. The solution of integration was done with Euler's method. The model was run until the system parameters were appropriately adjusted and the reasonable agreement between model results and field measurements were achieved. In order to test the ability of the calibrated model to predict water quality under different conditions, the model was run using a different set of water quality data taken in the month February 2014 for validation.

\section{Input Data}

\subsection{Water quality and flow data}

The water quality and flow data measured for calibration and validation of the model in the month of January and February 2014 is given in Tables 1 and 2, respectively. 
Table 1 . Some commonly used predictive re-aeration equations

\begin{tabular}{|c|c|c|c|c|c|c|c|c|c|c|}
\hline $\begin{array}{c}\text { Distance from } \\
\text { upstream } \\
\text { boundary, km }\end{array}$ & $\begin{array}{l}\text { Discharge/ } \\
\text { Withdrawal }\end{array}$ & $\underset{{ }^{\circ} \mathrm{C}}{\text { Temp. }}$ & $\mathrm{pH}$ & $\begin{array}{l}\text { BOD } \\
\mathrm{mg} / \mathrm{L}\end{array}$ & $\begin{array}{c}\text { DO } \\
\mathrm{mg} / \mathrm{L}\end{array}$ & $\begin{array}{c}\text { Org-N } \\
\mathrm{mg} / \mathrm{L}\end{array}$ & $\begin{array}{c}\mathrm{NH}_{4} \mathrm{~N} \\
\mathrm{mg} / \mathrm{L}\end{array}$ & $\begin{array}{c}\mathrm{NO}_{3-\mathrm{N}} \\
\mathrm{mg} / \mathrm{L}\end{array}$ & $\begin{array}{c}\text { Alkalinity } \\
\mathrm{mg} / \mathrm{L}\end{array}$ & $\begin{array}{l}\text { Flow } \\
\mathrm{m}^{3} / \mathrm{s}\end{array}$ \\
\hline 0.00 & $\begin{array}{l}\text { Head water } \\
\text { (main river) }\end{array}$ & 23.50 & 6.92 & 6.85 & 7.26 & 0.35 & 0.215 & 7.1 & 107 & 2.70 \\
\hline 0.28 & $\begin{array}{l}\text { Dhavelashwar } \\
\text { waste }\end{array}$ & 27.27 & 7.00 & 210 & 1.80 & 0.46 & 0.32 & 5.58 & 161 & 0.016 \\
\hline 2.64 & $\begin{array}{l}\text { Mudhol } \\
\text { abstract }\end{array}$ & -- & -- & -- & -- & -- & -- & -- & -- & 0.1950 \\
\hline 3.53 & Mudhol waste & 26.93 & 7.25 & 282 & 0.20 & 0.32 & 0.18 & 6.84 & 168 & 0.1120 \\
\hline 4.21 & $\begin{array}{l}\text { Chinchalkhandi } \\
\text { abstract }\end{array}$ & -- & -- & -- & -- & -- & -- & -- & -- & 0.0180 \\
\hline 4.92 & $\begin{array}{l}\text { Chinchalkhandi } \\
\text { waste }\end{array}$ & 27.82 & 7.42 & 215 & 0.80 & 0.28 & 0.12 & 6.88 & 142 & 0.0120 \\
\hline 7.50 & Budni abstract & -- & -- & -- & -- & -- & -- & -- & -- & 0.0175 \\
\hline 8.64 & Budni waste & 25.65 & 7.19 & 256 & 1.16 & 0.24 & 0.8 & 6.89 & 124 & 0.0110 \\
\hline
\end{tabular}

Table 2. The input water quality data for head water and point source in the month of February 2014

\begin{tabular}{|c|c|c|c|c|c|c|c|c|c|c|}
\hline $\begin{array}{l}\text { Distance from } \\
\text { upstream } \\
\text { boundary, km }\end{array}$ & $\begin{array}{l}\text { Discharge/ } \\
\text { Withdrawal }\end{array}$ & $\begin{array}{l}\text { Temp. } \\
{ }^{\circ} \mathrm{C}\end{array}$ & $\mathrm{pH}$ & $\begin{array}{l}\text { BOD } \\
\mathrm{mg} / \mathrm{L}\end{array}$ & $\begin{array}{l}\mathrm{DO} \\
\mathrm{mg} / \mathrm{L}\end{array}$ & $\begin{array}{l}\text { Org-N } \\
\mathrm{mg} / \mathrm{L}\end{array}$ & $\begin{array}{l}\mathrm{NH}_{4}-\mathrm{N} \\
\mathrm{mg} / \mathrm{L}\end{array}$ & $\begin{array}{l}\mathrm{NO}_{3}-\mathrm{N} \\
\mathrm{mg} / \mathrm{L}\end{array}$ & $\begin{array}{l}\text { Alkalinity } \\
\mathrm{mg} / \mathrm{L}\end{array}$ & $\begin{array}{l}\text { Flow } \\
\mathrm{m}^{3} / \mathrm{s}\end{array}$ \\
\hline 0.00 & $\begin{array}{l}\text { Head water } \\
\text { (main river) }\end{array}$ & 25.21 & 7.15 & 6.95 & 5.42 & 0.38 & 0.236 & 6.95 & 116 & 2.68 \\
\hline 0.28 & $\begin{array}{l}\text { Dhavelashwar } \\
\text { waste }\end{array}$ & 28.63 & 6.54 & 235 & 1.46 & 0.52 & 0.29 & 6.16 & 138 & 0.012 \\
\hline 2.64 & $\begin{array}{l}\text { Mudhol } \\
\text { abstract }\end{array}$ & -- & -- & -- & -- & -- & -- & -- & -- & 0.1926 \\
\hline 3.53 & Mudhol waste & 28.78 & 7.28 & 279 & 0.39 & 0.4 & 0.21 & 6.73 & 174 & 0.113 \\
\hline 4.21 & $\begin{array}{l}\text { Chinchalkhandi } \\
\text { abstract }\end{array}$ & -- & -- & -- & -- & -- & -- & -- & -- & 0.0180 \\
\hline 4.92 & $\begin{array}{l}\text { Chinchalkhandi } \\
\text { waste }\end{array}$ & 27.89 & 7.24 & 256 & 0.98 & 0.39 & 0.16 & 6.87 & 139 & 0.0120 \\
\hline 7.50 & Budni abstract & -- & -- & -- & -- & -- & -- & -- & -- & 0.0175 \\
\hline 8.64 & Budni waste & 26.64 & 6.98 & 267 & 1.15 & 0.31 & 0.96 & 6.62 & 167 & 0.0110 \\
\hline
\end{tabular}

\subsection{System parameters}

The ranges of model rate parameters were obtained from various literatures including Environmental Protection Agency (EPA) guidance document (George et al., 1985), the model user manual (Pelletier \& Chapra, 2005) and documentation for the enhanced stream water quality model QUAL2E, and QUAL2E -UNCAS (Brown \& Barnwell, 1987).

\section{Results And Discussion}

\subsection{Results of Calibration and Validation of the Model}

For calibration and validation of the model, six sampling points were selected in a $15 \mathrm{~km}$ reach between 
Dhavaleshwar and Mudhol at various distances. The results of BOD and DO predicted by the model and the actual values measured in the laboratory for calibration in the first week of January are given in Table 3 and represented graphically in Figs. 3 and 4. Similarly, the results of validation carried out in the first week of February are given in Table 4 and represented graphically in Figs. 5 and 6.

Table 3. Results of Calibration in the month of January 2014

\begin{tabular}{llllll}
\hline \multirow{2}{*}{ S1.No. } & $\begin{array}{c}\text { Distance } \\
\text { from } \\
\text { upstream } \\
\text { end, } \mathrm{km}\end{array}$ & $\begin{array}{l}\text { Predicted } \\
\text { value, } \\
\mathrm{mg} / \mathrm{L}\end{array}$ & $\begin{array}{l}\text { Measured } \\
\text { value, } \\
\mathrm{mg} / \mathrm{L}\end{array}$ & $\begin{array}{l}\text { Predicted } \\
\text { value, } \\
\mathrm{mg} / \mathrm{L}\end{array}$ & $\begin{array}{l}\text { Measured } \\
\text { value, } \\
\mathrm{mg} / \mathrm{L}\end{array}$ \\
\hline 1 & 2.5 & 6.70 & 7.52 & 6.63 & 7.08 \\
2 & 4.00 & 7.75 & 7.16 & 7.29 & 6.87 \\
3 & 6.5 & 7.57 & 8.48 & 7.53 & 6.22 \\
4 & 8.75 & 7.49 & 7.83 & 7.59 & 6.75 \\
5 & 11.25 & 7.23 & 6.81 & 7.58 & 7.12 \\
6 & 14.00 & 6.97 & 7.85 & 7.54 & 7.83 \\
1 & 2.5 & 6.70 & 7.52 & 6.63 & 7.08 \\
2 & 4.00 & 7.75 & 7.16 & 7.29 & 6.87 \\
\hline
\end{tabular}

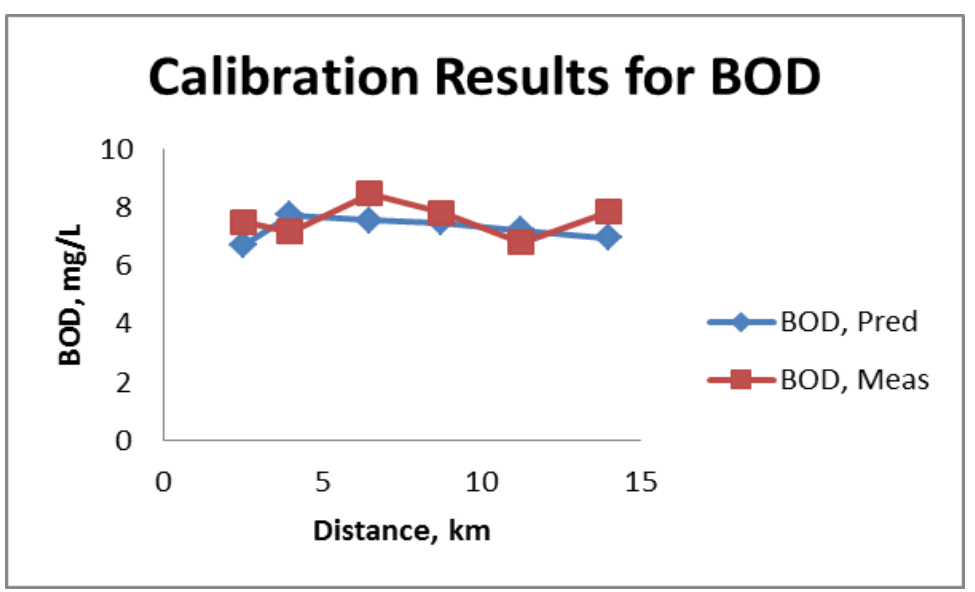

Fig. 3. Calibration Results for BOD of River Ghataprabha

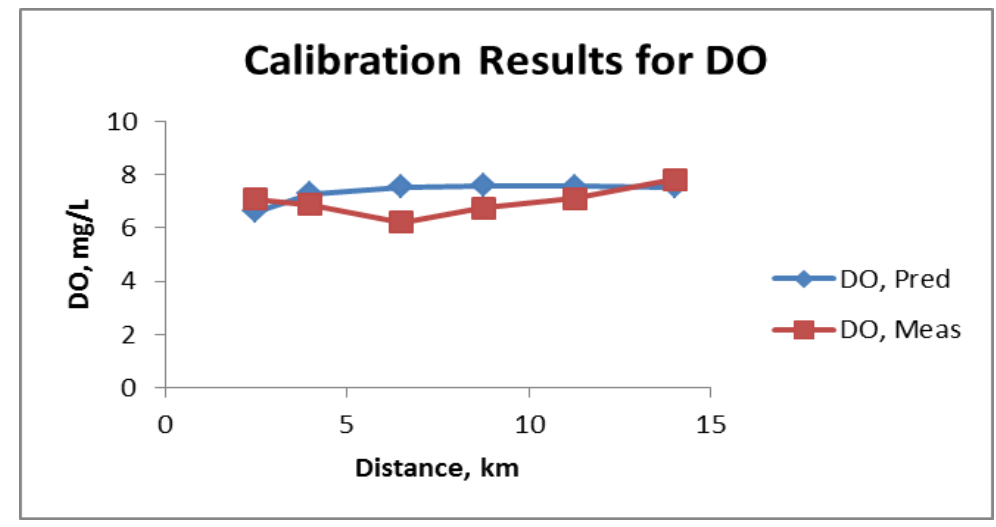

Fig. 4. Calibration Results for DO of River Ghataprabha 
Table 4. Results of Validation in the month of February 2014

\begin{tabular}{|c|c|c|c|c|c|}
\hline \multirow[t]{2}{*}{ Sl.No. } & \multirow{2}{*}{$\begin{array}{l}\text { Distance } \\
\text { from } \\
\text { upstream } \\
\text { end, km }\end{array}$} & \multicolumn{2}{|c|}{ BOD } & \multicolumn{2}{|c|}{ DO } \\
\hline & & $\begin{array}{l}\text { Predicted } \\
\text { value, } \\
\mathrm{mg} / \mathrm{L}\end{array}$ & $\begin{array}{l}\text { Measured } \\
\text { value, } \\
\mathrm{mg} / \mathrm{L}\end{array}$ & $\begin{array}{l}\text { Predicted } \\
\text { value, } \\
\mathrm{mg} / \mathrm{L}\end{array}$ & $\begin{array}{l}\text { Measured } \\
\text { value, } \\
\mathrm{mg} / \mathrm{L}\end{array}$ \\
\hline 1 & 2.5 & 7.83 & 7.43 & 6.48 & 6.62 \\
\hline 2 & 4.00 & 9.36 & 8.29 & 7.15 & 8.15 \\
\hline 3 & 6.5 & 10.11 & 11.23 & 7.32 & 6.23 \\
\hline 4 & 8.75 & 8.85 & 8.35 & 7.33 & 7.05 \\
\hline 5 & 11.25 & 7.19 & 7.69 & 7.29 & 6.9 \\
\hline 6 & 14.00 & 6.85 & 7.23 & 7.24 & 7.52 \\
\hline 1 & 2.5 & 7.83 & 7.43 & 6.48 & 6.62 \\
\hline 2 & 4.00 & 9.36 & 8.29 & 7.15 & 8.15 \\
\hline
\end{tabular}

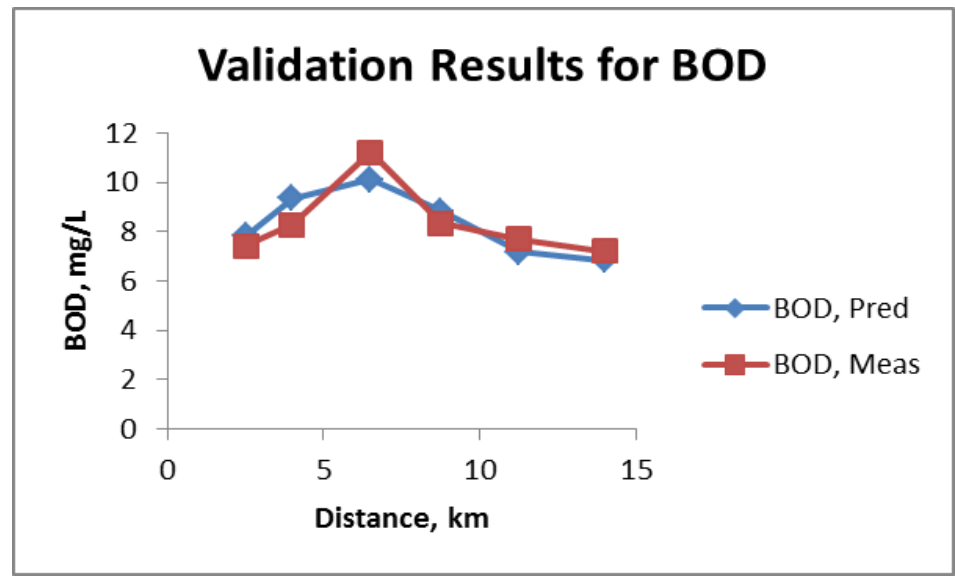

Fig. 5. Validation Results for BOD of River Ghataprabha

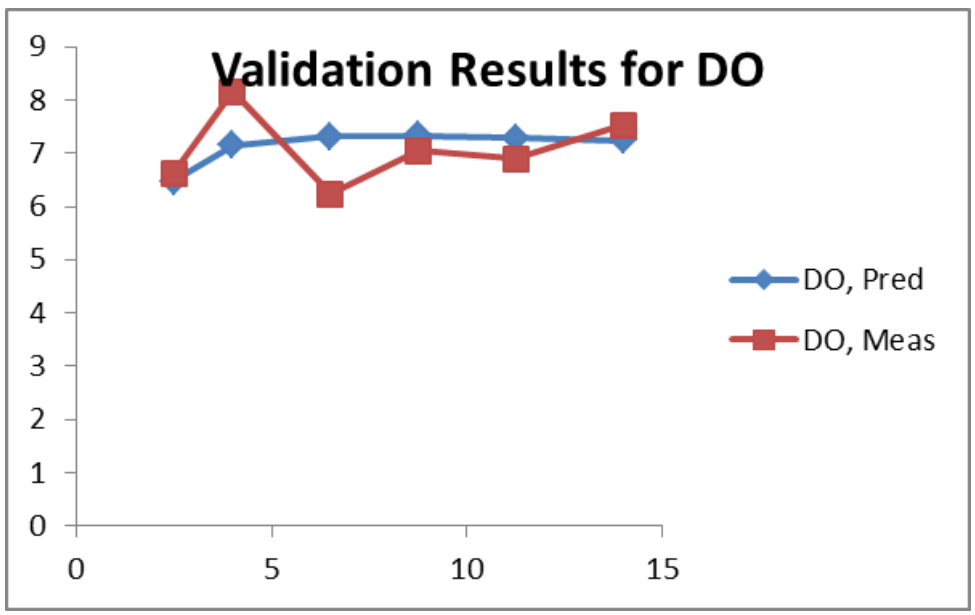

Fig. 6. Validation Results for DO of River Ghataprabha 


\subsection{Performance Evaluation of the Model}

From the results obtained for calibration and validation, the performance of the model was evaluated using statistics based on differential or standard errors (SE), Normalized mean error (NME) and mean multiplicative errors (MME). The background related to these parameters is available in Moog \& Jirka (1998).

The SE and NME which are differential errors are determined using the following equations.

$$
\begin{aligned}
& S E=\left[\sum_{i=1}^{N} \frac{\left(K_{p}-K_{m}\right)^{2}}{N}\right]^{\frac{1}{2}} \\
& N M E=\frac{100}{N} \sum_{i=1}^{N}\left(\frac{K_{p}-K_{m}}{K_{m}}\right)
\end{aligned}
$$

where $\mathrm{N}$ = number of measurements; KP and KM are predicted and measured value, respectively. The mean multiplicative error, MME, which may provide a better basis for assessing the impact of inaccuracies in predicting modelling equations, is defined as

$$
M M E=\exp \left[\frac{\left[\sum_{i=1}^{N} \ln \left(\frac{K_{p}}{K_{m}}\right)\right]}{N}\right]
$$

The SE, NME and MME values computed for both calibration and validation are given in Tables 5 and 6 and

\begin{tabular}{|c|c|c|c|}
\hline Parameter & SE & MME & NME \\
\hline BOD & 0.612 & 1.093 & -3.8 \\
\hline DO & 0.718 & 1.099 & 6.003 \\
\hline
\end{tabular}
represented graphically in Figs. 7 and 8, respectively.

Table 5. Error values of BOD and DO for Calibration of the Model

\begin{tabular}{|c|c|c|c|}
\hline Parameter & $\overline{\mathrm{SE}}$ & MME & NME \\
\hline BOD & 0.919 & 1.103 & -3.74 \\
\hline DO & 0.648 & 1.077 & 1.502 \\
\hline
\end{tabular}

Table 6. Error values of BOD and DO for Validation of the Model 


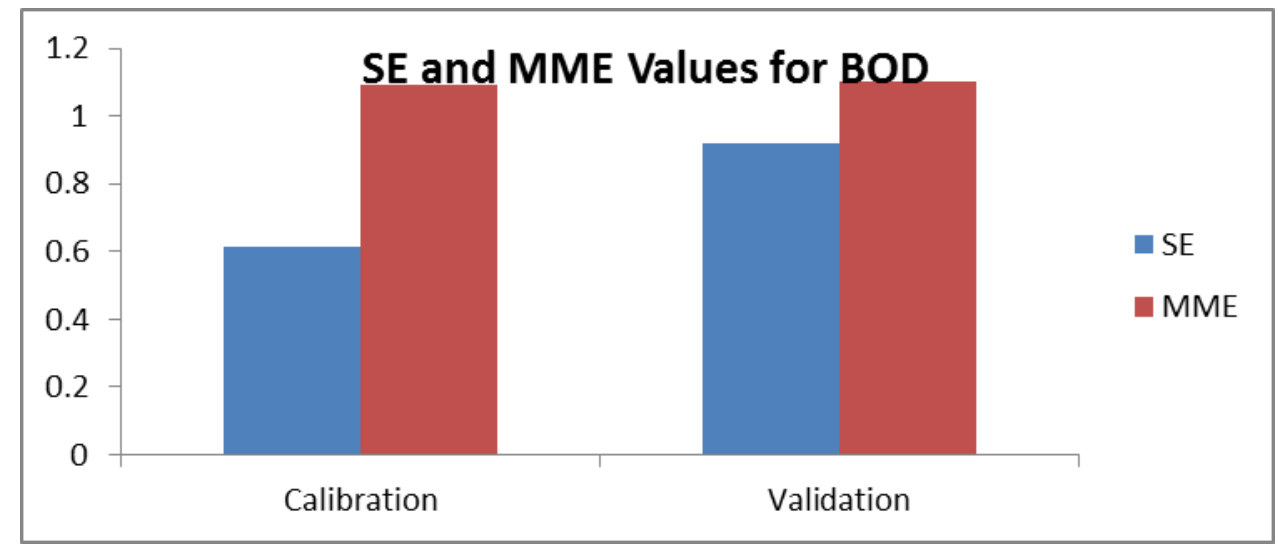

Fig. 7. SE and MME values for BOD during Calibration and Validation

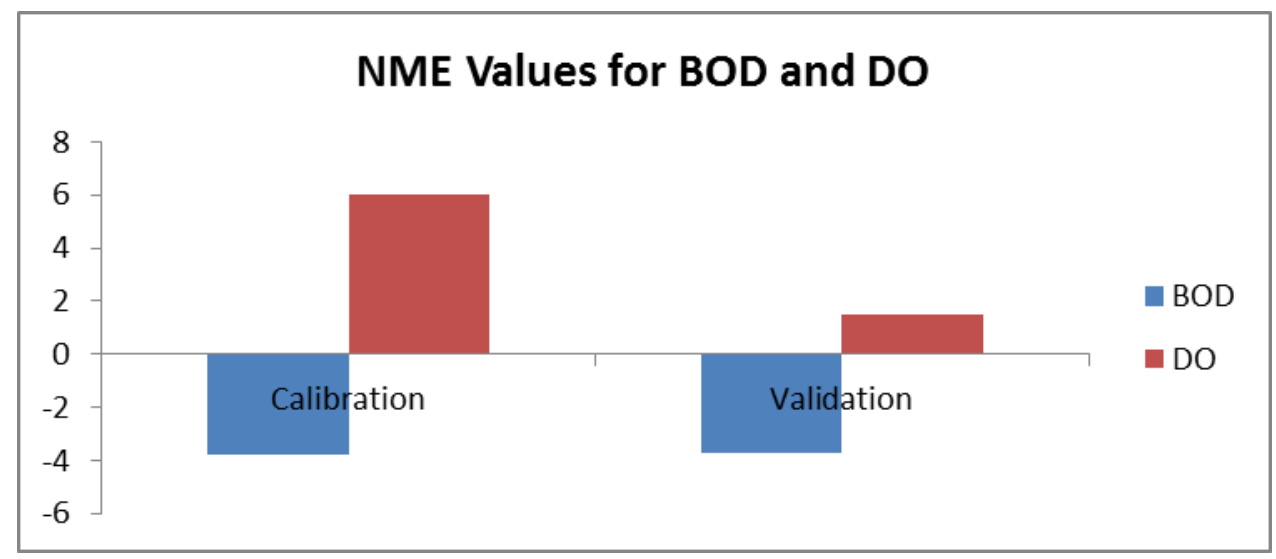

Fig. 8. NME values for BOD and DO during Calibration and Validation

From the results it can be observed that the standard errors for BOD during calibration are 0.612 and 0.919 respectively, and for DO, these values are 0.718 and 0.648 , respectively. Thus it can be said that the measured and predicted values are in close agreement with each other both during calibration and validation. Similarly, the values of MME also indicate that the there was not much deviation in the predicted and measured values both during calibration and validation. However, the NME values for BOD were -3.8 and -3.74 and the DO values were 6.003 and 1.502 during calibration and validation, respectively. From the NME values it can be observed that, even though the values for BOD are in close agreement both during calibration and validation, the deviation in the values of DO during calibration was more than that during validation of the model. This deviation may be due to some of the non point sources of pollution like the runoff from agricultural fields and rural areas which were not considered in the model. Agricultural activities were more during the month of January than in the month of February. Also lot of sand mining activities from the river bed was taking place in the month of January. Due to these mining activities deep pits were created in the river, which affect the rate of re-aeration of oxygen from the atmosphere. This might have also affected the level of measured values of DO from the predicted values. Over all, it can be said that the measured values and the values predicted by the model for both BOD and DO were in satisfactory range of agreement with each other except at few locations. 


\section{Conclusions}

A stream water quality model, QUAL2K, was calibrated and validated in a $15 \mathrm{~km}$ stretch of the river Ghataprabha from Dhavaleshwar to Mudhol during the month of January and February 2014, respectively. The results of calibration and validation of the model for BOD and DO at six monitoring locations showed that the values predicted by the model were in close agreement with measured values except at few locations. The performance of the model was evaluated using statistics based on Standard errors (SE), Normalized Mean Errors (NME) and Mean Multiplicative errors (MME).The results of the evaluation revealed that there is not much variation in these values between calibration and validation. The SE and MME values for BOD and DO during calibration are, 1.41 (1.12) and1.28 (0.90), respectively. The values in the bracket show MME. Corresponding values for the validation are $1.27(1.09)$ and $1.10(0.96)$. From the observation of error values it can be said that the model can be applied to obtain the predicted values which are practically in reasonable agreement with the measured values.

\section{References}

[1] Bhuvaneswaran NG, Rajeswari S. Water quality of river Adyar in Chennai city-The River a Boon or Bane. Indian J Env Protection 1999;19(6):412 - 5.

[2] Chapra SC, Pelletier GJ, Tao H. QUAL2K: A Modeling Framework for Simulating River and Stream Water Quality, Version 2.04: Documentation and Users Manual. Civil and Environmental Engineering Dept., Tufts University, Medford, MA; 2005.

[3] Brown LC, Barnwell Jr TO. The enhanced stream water quality models QUAL2E and QUAL2E-UNCAS: documentation and user manual. EPA/600/3-7/007, USEPA, Environmental Research Laboratory, Athens, GA, USA; 1987.

[4] APHA. Standard Methods for the Examination of Water and Wastewater: 20th ed. American Public Health Association, Washington, DC; 1998.

[5] George LB, William BM, Donald BP, Carrie LC, James RP, Gretchen LR, Kay MJ, Peter WHC, Steve AG, Charles EC. Rates, constants and kinetic formulations in surface water quality modelling. 2nd ed. U.S. Environmental Protection Agency, EPA/600/3-85/040; 1985.

[6] Pelletier GJ, Chapra SC. QUAL2KW theory and documentation (Version 5.1), a Modeling Framework for Simulating River and Stream Water Quality; 2005. online: http://w.w.w.ecy.wa.gov/programs/eap/models/.

[7] Moog DB, Jirka DH. Analysis of reaeration equations using mean multiplicative error. J. of the Env. Engg. Division, ASCE; 1998.

\section{Author(s) Profile}

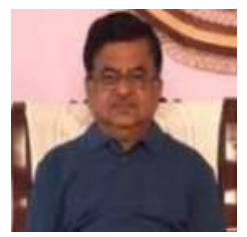

Dr. P. B. Kalburgi is Professor in Department of Civil Engineering at Basaveshwar Engineering College, Bagalkot, Karnataka, India. He did his B.E. in Chemical Engineering, M.Tech. and Ph.D. in Environmental Engineering. He has 10 years of industrial and 10 years of teaching experience. 


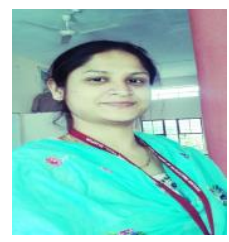

Ms. R. N. Shareefa is Assistant Professor in Department of Civil Engineering at SECAB institute of Engineering and Technology, Bijapur, Karnataka, India. She did her B.E. in Biotechnology, and M.Tech. in Environmental Engineering at Basaveshwar Engineering College, Bagalkot.

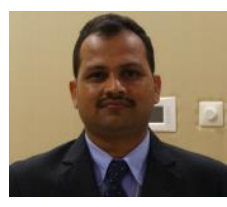

Dr. Umesh B. Deshannavar is Professor in Department of Chemical Engineering at KLE DR. M. S. Sheshgiri College of Engineering and Technology, Belgaum, Karnataka, India. He did his B. E. in Chemical Engineering, M.Tech. in Energy Systems Engineering, and Ph.D. in Chemical Engineering at Universiti Teknologi PETRONAS, Malaysia. He has 13 years of teaching experience.

How to cite this paper: P. B. Kalburgi, R. N. Shareefa, U. B. Deshannavar,"Development and Evaluation of BOD-DO Model for River Ghataprabha near Mudhol (India), using QUAL2K", IJEM, vol.5, no.1, pp.15-25, 2015.DOI: 10.5815/ijem.2015.01.02 